\author{
Research Article \\ www.ijrap.net (ISSN:2229-3566)
}

\title{
A CROSS-SECTIONAL STUDY ON BODY CONSTITUTION (DHEGA ILAKKANAM) IN UTHIRAVATHA SURONITHAM (RHEUMATOID ARTHRITIS)
}

S. Mahespriya ${ }^{1}$, H. Vetha Merlin Kumari ${ }^{2 *}$, H. Nalini Sofia ${ }^{2}$, T. Lakshmi Kantham ${ }^{3}$, R. Meena Kumari ${ }^{4}$

${ }^{1}$ PG scholar, Department of Maruthuvam, National Institute of Siddha, Chennai, Tamil Nadu, India

${ }^{2}$ Associate professor, Department of Maruthuvam, National Institute of Siddha, Chennai, Tamil Nadu, India

2. Associate professor, Department of Maruthuvam, National Institute of Siddha, Chennai, Tamil Nadu, India

${ }^{3}$ Associate professor, Head of the department (i/c), Department of Maruthuvam, National Institute of Siddha, Chennai, Tamil Nadu, India

${ }^{4}$ Director, Professor, Head of the department of Gunapadam, National Institute of Siddha, Chennai, Tamil Nadu, India

Received on: 28/07/21 Accepted on: 09/09/21

*Corresponding author
E-mail: dr.vetha@gmail.com

DOI: $10.7897 / 2277-4343.1205140$

ABSTRACT

Background: Siddha medicine is an ancient script of medicine has been originated in South India. The concept of the Siddha system is based on fundamental principles of 96 thathuvangal which include five basic elements of the Universe, Udal thadhugal, and Uyir thadhugal etc. The physical health of the human body is maintained by three humors vathm, pitham, kabam which are the basic vital forces of humans. Udaliyal assessment is an essential tool, to diagnose any variation in the three vital forces. This study was to evaluate the body constitution in Uthiravatha Suronitham (Rheumatoid arthritis). This study was conducted in the outpatient department maruthuvam, Ayothidoss pandithar hospital, National Institute of Siddha, Chennai. 50 Uthiravatha Suronitham patients were selected to analyze the body constitution of Uthiravatha suronitham disease. The study details were collected by using the questionnaire in the data collection questionnaire. vathakaba thegi and vathapitha thegi body constitutions were more prone to Uthiravatha suronitham disease. The traits of thega illakanam, can be used for the line of treatment to the Uthiravatha suronitham patients along with dietary habits, behavioural modifications. etc.

Keywords: Siddha system, Body constitution, Uthiravatha suronitham, Rheumatoid arthritis.

\section{INTRODUCTION}

The Uyirthaadhu comprises vatham (vali), pitham (Azhal), kabam (Iyam). These three vital forces form the individual yakkai ilakkanam (Body constitution) ${ }^{1}$. Udaliyal is classified into Nine types, which forms due to the dominating level of vatham, pitham, kabam influence. When the three humours are affected by lifestyle modification, seasonal variation they cause the diseases $^{2}$.

In Yugi vaithiya chinthamani vatha diseases are classified into 80 types. In which, Uthiravatha Suronitham is one among them. Signs and symptoms of Uthiravatha Suronitham may be correlated with Rheumatoid arthritis ${ }^{3}$. Rheumatoid arthritis is a chronic inflammatory, destructive, and deforming symmetrical polyarthritis associated with systemic involvement. The individuals are being with HLA - DR4 and HLA- DR1 and familial aggregation. It is characterized by deforming symmetrical polyarthritis of varying extent and severity, associated with synovitis of joints and tendon sheaths, articular cartilage loss, erosion of extra-articular bone, presence of IgM rheumatoid factor in the blood, which occurring through out of the world 3 to 4 decade of life $e^{4,5}$. The prevalence of the RA is approximately $0.8-1.0 \%$ in Europe and India, with a female to male ratio of $3: 1 .^{6}$

This study was conducted to evaluate the body constitution (vatham, pitham, kabam) of Uthiravatha suronitham noi and evaluate the personal characteristics of Uthiravatha suronitham patients with personal history, family history, dietary habits etc.

\section{MATERIALS AND METHODS}

A cross-sectional study was conducted in the outpatient department of Maruthuvam in Ayothidoss pandithar hospital, National Institute of Siddha. This study was approved by IEC (Institutional Ethics Committee)-NIS/IEC/2020/MP-5. The study was also registered in CTRI (Clinical Trial Registry India)CTRI/2020/06/026155. In this study, 50 outpatients in between 18-70 age groups were selected without any bias. The study details were collected in the pre-designed data collection questionnaire. ${ }^{2,7}$

\section{OBSERVATION AND RESULT}

Table 1: Gender

\begin{tabular}{|c|c|c|}
\hline $\begin{array}{c}\text { Gender } \\
\text { distribution }\end{array}$ & $\begin{array}{c}\text { Number of } \\
\text { patients }\end{array}$ & Percentage \\
\hline Male & 8 & $16 \%$ \\
\hline Female & 42 & $84 \%$ \\
\hline
\end{tabular}

Table 2: Age

\begin{tabular}{|c|c|}
\hline Age & Number of patients (\%) \\
\hline $18-20$ & $1(2 \%)$ \\
\hline $21-30$ & $5(10 \%)$ \\
\hline $31-40$ & $14(28 \%)$ \\
\hline $41-50$ & $15(30 \%)$ \\
\hline $51-60$ & $13(26 \%)$ \\
\hline $61-70$ & $2(4 \%)$ \\
\hline
\end{tabular}


Table 3: Food Habit

\begin{tabular}{|c|c|c|}
\hline Food habit & Number of peoples & Percentage \\
\hline Veg & 2 & $4 \%$ \\
\hline Non Veg & 45 & $90 \%$ \\
\hline Lacto Veg & 3 & $6 \%$ \\
\hline
\end{tabular}

Table 4: Family history

\begin{tabular}{|c|c|c|}
\hline $\begin{array}{c}\text { Family } \\
\text { history }\end{array}$ & $\begin{array}{c}\text { Number of } \\
\text { patients }\end{array}$ & Percentage \\
\hline Yes & 11 & $22 \%$ \\
\hline No & 39 & $78 \%$ \\
\hline
\end{tabular}

Table 5: Psychological factors

\begin{tabular}{|c|c|c|}
\hline $\begin{array}{c}\text { Psychological } \\
\text { factors }\end{array}$ & $\begin{array}{c}\text { Number of } \\
\text { patients }\end{array}$ & Percentage \\
\hline Anxiety & 6 & $12 \%$ \\
\hline Stress & 14 & $28 \%$ \\
\hline Emotion & 17 & $34 \%$ \\
\hline Depression & 6 & $12 \%$ \\
\hline $\begin{array}{c}\text { No Psychological } \\
\text { Disturbances }\end{array}$ & 7 & $14 \%$ \\
\hline
\end{tabular}

Table 6: Naadi

\begin{tabular}{|c|c|c|}
\hline Naadi & $\begin{array}{c}\text { Number of } \\
\text { patients }\end{array}$ & Percentage \\
\hline Vathapitham & 19 & $38 \%$ \\
\hline Vathakabam & 7 & $14 \%$ \\
\hline Pithavatham & 13 & $26 \%$ \\
\hline Pithakabam & 3 & $6 \%$ \\
\hline Kabavatham & 7 & $14 \%$ \\
\hline Kabapitham & 1 & $2 \%$ \\
\hline
\end{tabular}

Table 7: Thegi

\begin{tabular}{|c|c|c|}
\hline Thegi distribution & $\begin{array}{c}\text { Number of } \\
\text { patients }\end{array}$ & Percentage \\
\hline Vathapitham & 17 & $34 \%$ \\
\hline Vathakabam & 18 & $36 \%$ \\
\hline Pithavatham & 6 & $12 \%$ \\
\hline Pithakabam & 3 & $6 \%$ \\
\hline Kabavatham & 4 & $8 \%$ \\
\hline Kabapitham & 2 & $4 \%$ \\
\hline
\end{tabular}

\section{INFERENCE}

For the study on Uthiravatha suronitham Noi, 50 patients were included in this study 42 (84\%) cases were female, and $8(16 \%)$ cases were male.

The participants were found to be predominantly in the age group of $41-50(30 \%)$ while the least occurred in the age group of 18 $20(2 \%)$.

Out of 50 patients, 45 (90\%) cases were non-vegetarian, 2 (4\%) cases were vegetarian and $3(6 \%)$ of cases were Lacto vegetarian. Out of 50 patients, 39 (78 \%) cases had no relevant family history, and $11(22 \%)$ cases had a family history of Uthiravatha suronitham Noi.

Out of 50 patients, 17 (34\%) cases were being with Emotion, 14 $(28 \%)$ cases were being with stress, $6(12 \%)$ cases were being with Anxiety and Depression and $7(14 \%)$ cases had no psychological factors.
Out of 50 patients, 19 (38\%) cases had Vathapitha naadi, 13 (26 $\%)$ cases had pithavatha naadi, 7 (14\%) cases had Vathakaba and Kabavatha naadi, 3 (6\%) cases had Pithakaba naadi, and 1 (2\%) case had Kabapitha naadi.

Out of 50 patients, 18 (36\%) cases were Vathakaba thegi, 17 (34 $\%)$ cases were Vathapitha thegi, $6(12 \%)$ cases were Pithavatha thegi, 4 (8\%) cases were Kabavatha thegi, 3 (6\%) cases were Pithakaba thegi, 2 (4\%) cases were Kabapitha thegi.

\section{DISCUSSION}

Siddha system has a unique diagnostic method to identify the disease and causative agents.

According to Theraiyar, diagnostic methods are classified as

"Meikuri niram thoni vizhinaa irumalam kaikuri" 2

There are eight tools of diagnostic methods which also include thega illakanam and seven udal thadhukkal.

"Naadisparisam naaniram mozhivizhi

Malam moothiramivai maruthuvarautham"

Eight tools consist of naa, niram, mozhi, vizhi, saprism, naadi, neerkuri, neikuri, malam. ${ }^{2}$

The autoimmune disease is generally influenced by genetic, hormonal, and environmental factors. Autoimmune disease is more common in females than males, hence the etiology of RA is influenced by estrogen and progesterone. Therefore, females had a higher incidence of RA. ${ }^{8,9}$ In this study among 50 patients, 42 $(84 \%)$ patients were females, and $8(16 \%)$ patients were males $(p<0.05)$ the study result is statistically significant.

Clinically 3 to 4 decades of life Rheumatoid arthritis is more common, in this study among 50 patients, 41-50 years of age group includes $15(30 \%)$ patients, $31-40$ years of age groups includes 14 (28\%) patients, 51-60 years of age group includes 13 (26\%) patients, 21-30 years of age group includes $5(10 \%)$ patients, $61-70$ years of age groups includes $2(4 \%)$ patients, 18 20 years of age groups includes $1(2 \%)$ patient. ${ }^{4,5}$

Family history plays a major role in the incidence of valiazhal keelvayu (Rheumatoid arthritis).

"Kalitharu muyakkam perror

Kadiseyal karuviyamaal" 10

In this study among the 50 patients, $11(22 \%)$ patients had a family history of rheumatoid arthritis $(p<0.05)$ and the study result is statistically significant.

Depression is one of the ${ }^{11}$ major problems in Rheumatoid arthritis; it was studied in the British Society of Rheumatology. On studying psychological factors among 50 patients, 17 (34\%) cases were being with Emotion, 14 (28\%) cases were being with stress, $6(12 \%)$ cases were being with Anxiety and Depression, 7 $(14 \%)$ cases had no psychological illness $(p<0.05)$ and study result is statistically significant.

By educating Siddhar Theraiyar kaalaolukkam to patients, which gives good psychological support and yoga to get rid of depression. Those who are rise at dawn will have clear intellect and the neurological function will be proper, the three humours will be in equilibrium. ${ }^{12,13}$ 
According to Sathaga naadi, Vathapitha naadi occurred in Vathanoikal,

"Porulaana vathathil pitham sernthu

Karuvaana thegamathi ulaichal sombal

According to Thirattu naadi states that,

"Enneeya vathamrandu pithamon nezhuntha thakil

Punnana udambu novum pugaiyena erium nenju" 2

Hence vatham and pitham altered in Rheumatoid arthritis patients. Among 50 patients $19(38 \%)$ patients had vathapitha naadi, $13(26 \%)$ patients had pithavatha naadi, $7(14 \%)$ patients had Vathakaba and Kabavatham naadi, 3 (6\%) patients had Pithakaba naadi, and 1 (2\%) patient had Kabapitha naadi.

On analyzing thega illakanam, Vathakaba and Vathapitha thontha thegi had a higher incidence of Uthiravatha suronitham (Rheumatoid arthritis) among 50 patients, 18 (36\%) patients were Vathakaba thegi, 17 (34\%) patients were Vathapitha thegi, $6(12 \%)$ patients were Pithavatha thegi, $4(8 \%)$ patients were Kabavatha thegi, 3 (6\%) patients were Pithakaba thegi, 2 (4\%) patients were Kabapitha thegi.

If one wants to be free from disease of three humours, he should take the food cooked with pepper, turmeric, cumin seeds, asafoetida, dried ginger, cardamom, fenugreek, and garlic. ${ }^{14,15}$

Thiridhoda samaporulkal, which brings the three humors to a normal state. Thiridhoda samaporulkal act as adjuvant therapy and have an immunomodulatory effect thus reduce the severity of Rheumatoid arthritis. ${ }^{16}$

The data were analyzed by Chi-square test, result showered that expected and observed frequencies of Food habits, Gender, Family history and psychological factors $(\mathrm{p}<0.05)$ are statically significant.

\section{CONCLUSION}

This minor project result revealed that vathakaba and vathapitha thondha thegi body constitution was more prone to Uthiravatha suronitham (Rheumatoid arthritis). Vathapitha naadi was found to be associated with Uthiravatha suronitham noi. These findings could be additional support to select the line of treatment in rheumatoid arthritis patients according to the body constitution.

\section{REFERENCES}

1. Muthiah K, Ganesan K, Ponnaiah M, Parameswaran S. Concepts of body constitution in traditional Siddha texts: A literature review. J Ayurveda Integr Med. 2019 AprJun;10(2):131-134. DOI: 10.1016/j.jaim.2019.04.002.Epub 2019 May 25. [Cited on 2020 March 5], Available from: https://pubmed.ncbi.nlm.nih.gov/31138488]

2. M. Shanmugavelu, Noinaadal Noimuthalnaadal thirattu Paagam 1, 3rd Edition, p 182,245,270, Directorate of Indian Medicine and Homeopathy, 2003.

3. Ka. Anbarasu, Yugivaithiya chinthamani, $2^{\text {nd }}$ Edition, $p$ 100, Directorate of Indian Medicine and Homeopathy, 2005.
4. Harsh mohan, Textbook of pathology, $7^{\text {th }}$ Edition, $p 843$ -844, Jaypee brother's medical publishers, 2015.

5. John A. A. Hunter, Davidson's principle and practice medicine, 20 $0^{\text {th }}$ Edition 2006, p 1088.

6. Malaviya AN, Kapoor SK, Singh RR, Kumar A, Pande I. Prevalence of rheumatoid arthritis in the adult Indian population. Rheumatol Int. 1993;13(4):131-4. DOI: 10.1007/BF00301258. [Cited on 2020 March 5], Available from: https://pubmed.ncbi.nlm.nih.gov/8310203].

7. The central council for Research in Ayurveda and Siddha, Clinical research protocols for traditional health sciences, Department of AYUSH, Ministry of health and family welfare Government of India, New Delhi, 2010, p 18.

8. Van Venrooij WJ, Pruijn GJ. Citrullination: a small change for a protein with great consequences for rheumatoid arthritis. Arthritis Res. 2000; 2(4):249-51. DOI: 10.1186/ar95. Epub2000 May24. [Cited on 2021 July 27], Available from: https://pubmed.ncbi.nlm.nih.gov/11094435]

9. Sokka T, et al. QUEST-RA Group. Women, men, and rheumatoid arthritis: analyses of disease activity, disease characteristics, and treatments in the QUEST-RA study. Arthritis Res Ther. 2009;11(1): R7. DOI: 10.1186/ar2591. Epub 2009 Jan 14. [https://pubmed.ncbi.nlm. nih.gov/19144159]

10. K. N. Kuppusamy Muthaliyar, Siddha Maruthuvam pothu, $8^{\text {th }}$ Edition, p 608-609,627, Directorate of Indian Medicine and Homeopathy, 2016.

11. Sheehy C, Murphy E, Barry M. Depression in rheumatoid arthritis--underscoring the problem. Rheumatology (Oxford). 2006 Nov;45(11):1325-7. DOI: 10.1093/rheumatology/kel 231.Epub2006Aug14. [Cited on $2020 \mathrm{March}$ ], Available from: https://pubmed.ncbi.nlm. nih.gov/16908510].

12. Anaivaari, R. Anandan, A compendium of Siddha Doctrine, $1^{\text {st }}$ Edition, p 11, 74,124,163,193, Directorate of Indian Medicine and Homeopathy, 2005.

13. Neha Rawat et al. Ayurvedic treatment of Rheumatoid Arthritis: A Case Study. Int. J. Res. Ayurveda Pharm. 2021;12(1):1-4 DOI: http://dx.doi.org/10.7897/22774343.12011

14. K.S. Uththamarayan, Siddha maruthuvanga churukkam, $3^{\text {rd }}$ Edition, p 657,416,418, Directorate of Indian Medicine and Homeopathy, 2016.

15. Agarwal Vivek, Dubey Mukesh, Naresh Kumar. Concept of ama with special reference to clinical evaluation and therapeutic view on Amavata (Rheumatoid arthritis). Int. J. Res. Ayur. Pharm. 2013; 4(1):23-26 [cited on 2021 July 27] Doi: DOI: $10.7897 / 2277-4343.04116$

16. Vadell AKE et.al. Anti-inflammatory diet in rheumatoid arthritis (ADIRA) - A randomized controlled crossover trial indicating effects on disease activity, The American journal of clinical nutrition, 2020; Jun 1;111(60:1203-1213). [Cited on 2020 March 4]; Available from: https://pubmed. ncbi.nlm.nih.gov/32055820/

\section{Cite this article as:}

S. Mahespriya et al. A cross-sectional study on body constitution (Dhega ilakkanam) in uthiravatha suronitham (Rheumatoid arthritis). Int. J. Res. Ayurveda Pharm. 2021;12(5):42-44 http://dx.doi.org/10.7897/2277-4343.1205140 